\title{
Post-Emergence Movements and Overwintering of Snapping Turtle, Chelydra serpentina, Hatchlings in New York and New Hampshire
}

\author{
Gordon R. Ultsch ${ }^{1,2}$, Matt Draud ${ }^{3}$, and BarRy Wicklow ${ }^{4}$ \\ ${ }^{1}$ Corresponding author: Courtesy Professor, Department of Zoology, University of Florida, Gainesville, Florida 32611 USA \\ ${ }^{2}$ Mailing address: 4324 NW 36th St., Cape Coral, Florida 33993 USA; e-mail: gultsch@ bama.ua.edu \\ ${ }^{3}$ Department of Biology, C. W. Post - Long Island University, 720 Northern Boulevard, Brookville, New York 11547 USA \\ ${ }^{4}$ Department of Biology, St. Anselm College, 100 Saint Anselm Drive, Manchester, New Hampshire 03102 USA
}

Ultsch, Gordon R., Matt Draud, and Barry Wicklow. 2007. Post-emergence movements and overwintering of Snapping Turtle, Chelydra serpentina, hatchlings in New York and New Hampshire. Canadian Field-Naturalist 121(2): $178-181$.

Hatchling Common Snapping Turtles (Chelydra serpentina) were captured within, or as they emerged from, their nest cavities in Long Island, New York, and in southeastern New Hampshire. They were fitted with radiotransmitters and released at their nest sites. Their movements were monitored for as long as possible, which for some included tracking them to their overwintering sites and relocating them the following spring. On Long Island, all hatchlings initially moved to water. Later movements were both aquatic and terrestrial, and those that could be located while overwintering had left the water and hibernated in spring seeps, where they were recovered alive the following April. In New Hampshire, hatchlings moved directly to nearby aquatic habitats after emergence, where they spent the winter submerged in shallow water in root masses near banks.

Key Words: Common Snapping Turtle, Chelydra serpentina, hatchling turtles, hibernation in turtles, New York, New Hampshire.

In northern climates, the behavior of hatchling aquatic turtles, once they have pipped and left the eggshell, is variable both among and within species. In some species the majority of hatchlings remain in the nest until the following spring, although some fall emergence may occur. These include Painted Turtles (Chrysemys picta - Zwiefel 1989; Lindeman 1991; Pappas et al. 2000), Common Map Turtles (Graptemys geographica - Pappas et al. 2000; Baker et al. 2003; Nagle et al. 2004), and Diamondback Terrapins (Malaclemys terrapin; Baker et al. 2006). For the two former species, it is assumed that if the hatchlings leave the nest, they overwinter aquatically, while for the latter species fall emergence coupled with aquatic or terrestrial overwintering has been reported (Draud et al. 2004), as well as overwintering in the nest coupled with fall emergence (Baker et al. 2006). Other species have been consistently reported to be overwhelmingly fall emergers, including Snapping Turtles (Chelydra serpentina - Obbard and Brooks 1981; Carroll and Ultsch 2007), Spiny Softshell Turtles (Apalone spinifera - Christiansen and Gallaway 1984; Costanzo et al. 1995), Musk Turtles (Sternotherus odoratus Cagle 1942; Mitchell 1988), Wood Turtles (Glyptemys insculpta - Harding 1991; Carroll and Ultsch 2007), Spotted Turtles (Clemmys guttata - Ernst 1976; Carroll and Ultsch 2007), and Blanding's Turtles (Emydoidea blandingii - Standing et al. 1997, 1999; Pappas et al. 2000). Hatchlings of most of these species are assumed to overwinter aquatically, even though some may remain on land for extended periods before entering the water; e.g., Wood Turtles (Tuttle and Carroll 2005; Castellano, Behler, and Ultsch, unpub- lished data) and Blanding's Turtles (Standing et al. 1997, 1999). However, there are some reports of suspected terrestrial overwintering in the hatchlings of some of these species, based largely on the capture of one or a few individuals in spring in microhabitats that are suggestive of non-aquatic overwintering (Ernst 1966, 1976; Standing et al. 1997; Pappas et al. 2000, Parren and Rice 2004). While such behavior does not appear common, its degree of occurrence is uncertain.

There are no reports of following individual hatchlings from the time of emergence from the nest until the resumption of activity the next spring. The typical approach of a study of overwintering behavior, a number of which have been done with adult turtles (reviewed by Ultsch 2006), has been the use of radiotelemetry, permitting tracking of the turtles throughout the hibernation period, including entrance and exit. Recently, transmitters small enough to attach to hatchlings have become available, which allows tracking of the animals from the nest to their wintering grounds, although battery life is not yet long enough to track the turtles until the following spring. However, once the turtles go into hibernation, they move little, which potentially allows recovery during the early spring before movement is resumed.

Here we report on the post-emergence and overwintering behavior of Snapping Turtle (Chelydra serpentina) hatchlings in Long Island, New York, and in southeastern New Hampshire. In both localities the hatchlings moved to water rather directly, but their eventual overwintering sites differed considerably at the two locations. 


\section{Methods}

On Long Island, 15 Snapping Turtle hatchlings were collected in the nest on 11 September 2004 from two nest sites (seven from one and eight from the other) in the vicinity of Cold Spring Harbor, Nassau County. The nests were located along an earthen dam separating a lake from the stream formed by the dam overflow. They were brought to the laboratory, fitted with 0.9 g BD-2 transmitters (Holohil Systems Ltd., Carp, Ontario, Canada) attached to the carapace with cyanoacrylate glue (Krazy Glue ${ }^{\circledR}$ ), and released into their respective nest cavities on 13 September 2004. All hatchlings left the nest cavity within $10 \mathrm{~min}$. Telemetry commenced on 14 September, using a Communication Specialists model R1000 receiver. The expected life of the transmitters was 30 days, and some were replaced on day 30. Whenever possible, a visual location was paired with the telemetric location, which was recorded with a hand-held Magellan GPS 315. Hatchlings were located on nine days from 14-30 September, 10 days from 2-28 October, and on 5 and 12 November. Five hatchlings were lost during the study. Hatchlings that entered final hibernation sites were marked by surveyor flags for recovery, which occurred on 5 April 2005.

In New Hampshire, hatchlings were collected from both riverine and palustrine habitats. Six hatchlings were collected from a nest site $20 \mathrm{~m}$ from a third-order stream (riverine site) and 18 hatchlings were collected from two adjacent nests $3 \mathrm{~m}$ from a first-order stream (palustrine site) within a wetland complex. On $17 \mathrm{Sep}-$ tember 2005 six hatchlings from the riverine site were brought to the laboratory and fitted with $0.5 \mathrm{~g}$ A2415 transmitters (Advanced Telemetry Systems [ATS], Inc., Isanti, Minnesota) attached to the carapace with epoxy resin. They were released at the nest site on $19 \mathrm{Sep}$ tember 2005. Hatchlings were located using an ATS FM-100 receiver and their GPS coordinates recorded using a Trimble Geoexplorer 3. At the palustrine site, nine hatchlings emerging from a nest (22 September 2005) were fitted on site with Holohil transmitters (see above) attached to the carapace using epoxy resin. These hatchlings were then returned to the nest. After a flash flood event during the first week of October 2004, 12 hatchlings were lost. At that time transmitters were attached on site to eight additional hatchlings captured at the site in shallow water. Hibernation sites were marked using surveyor flags. These sites were searched in March 2006.

\section{Results}

On Long Island, 10 hatchlings were followed. The transmitter became detached from three after their movement to water. Two others were found dead. One moved to the water and was found dead on a beach after 26 days. One exhibited considerable movement activity (34-260 $\mathrm{m}$ between location periods), including some terrestrial movements, and by 5 October had moved to a seep, buried in leaves near the surface; it was found dead there on 3 April at a depth of $5 \mathrm{~cm}$. One moved into and out of water and then back into the water, and was located on 12 November dug into sand under a tree root in about $8 \mathrm{~cm}$ of water. This animal could not be located the following April.

Four hatchlings were tracked to their hibernation quarters and located the following spring. One moved immediately to water, then was found on 2 October under a $\log 8 \mathrm{~m}$ from water. By 10 October it had moved uphill to a spring seep, and two days later had dug to about $20 \mathrm{~cm}$ depth and did not move through 12 November. It was found alive and responsive at the same site on the following 3 April in $8 \mathrm{~cm}$ of saturated mud. A second moved directly to water and then emerged onto land on 30 September about $1.5 \mathrm{~m}$ from the water. By 2 October it had moved to a site about $20 \mathrm{~m}$ from the water, where it buried under leaves and remained until 8 October. By 10 October it had moved $15 \mathrm{~m}$ and was at the surface under cat briar. On 12 October it had moved to a second spring seep, where it buried, moved, and reburied over a 6-day period to depths of 10-13 cm. By 21 October it had relocated in the seep and buried to about $15 \mathrm{~cm}$ and had not moved by the last observation on 12 November. It was found alive and alert near the surface at the same location on 3 April. A third moved to water, and moved aquatically until 30 September, when it moved into the same seep area as the second, where it moved intermittently, being found buried at depths of $8-13 \mathrm{~cm}$ until 18 October, when it settled into the wet organic detritus along the side of a fallen tree, and had not moved by 12 November. It overwintered there and was found alive and well at the surface of the mud at the same site on 3 April. A fourth moved to and about in shallow water for five days. By the seventh day it had left the water and buried into moist sphagnum moss about $0.25 \mathrm{~m}$ from shore for 3-5 days without moving. It then moved back to water for 2-3 days and then back onto land on 30 September, where it buried for three weeks about $8 \mathrm{~cm}$ into the same seep used by the second and third hatchlings. It then moved downward to about $15 \mathrm{~cm}$ by 21 October and did not move through 12 November. It was recovered alive at this site on 3 April.

In New Hampshire, at the riverine site, 5 of 6 hatchlings moved first up a gentle slope and then down a steep slope to the river $6 \mathrm{~m}$ below. Three of these entered the river within $3 \mathrm{~h}$ of release, one after $24 \mathrm{~h}$, and one after $36 \mathrm{~h}$. The sixth moved $8 \mathrm{~m}$ on land, down a slope, and burrowed under leaves and then entered the water the next day, all within $24 \mathrm{~h}$ of release. The hatchlings remained within $20 \mathrm{~m}$ of their entrance points into the river, remaining in shallow $(2-3 \mathrm{~cm})$ water, and often buried in sand or detritus with only the head exposed. After extreme flooding caused by heavy rains $(25-30 \mathrm{~cm}$ in 3 days) in early October, the hatchlings were lost. Three detached transmitters were 
found, suggesting significant buffeting of the hatchlings.

At the palustrine New Hampshire site, 15 hatchlings (five with and 10 without transmitters) traveled 3-5 m to enter a nearby wetland stream within $4 \mathrm{~h}$ of release. Of the four additional hatchlings with transmitters, one burrowed back into the sand of the nest, where it remained for 2 days until dug out by a predator. Two more entered the water within $24 \mathrm{~h}$, and the fourth traveled $5 \mathrm{~m}$, remained under wetland vegetation for one day, burrowed into sand one day, then traveled $20 \mathrm{~m}$ to shallow water $(8 \mathrm{~cm})$ at the edge of the stream. Six hatchlings were lost after a flood during the first week of October. On 11 October 2005, eight additional hatchlings were located along the stream within $5 \mathrm{~m}$ of the nest. Each was fitted with a transmitter on site and then returned to the stream. Of these, one moved $15 \mathrm{~m}$ downstream into the flooded wetland within $24 \mathrm{~h}$, two moved 12 and $17 \mathrm{~m}$ downstream into the wetland by 16 October 2005 . A fourth moved $15 \mathrm{~m}$ into the wetland by 2 November 2005. Four hatchlings remained tucked into roots of sedges and silky dogwood in $2-3 \mathrm{~cm}$ water along the edge of the wetland stream, 3-5 $\mathrm{m}$ from the nest. A fifth had remained in this location since 22 September 2004 (visually located on 2 November 2005). Three hatchlings were relocated in March 2006, and they were all at the locations at which they were last observed in November 2005. One was located on 8 March, $6 \mathrm{~cm}$ below the surface and $2.5 \mathrm{~m}$ from the nest site, under sedge roots at the edge of the stream in $1^{\circ} \mathrm{C}$ water. A second was found on 8 March, $6 \mathrm{~cm}$ below the surface in $1^{\circ} \mathrm{C}$ water under leaves at the base of a submerged log in the wetland $15 \mathrm{~m}$ from its nest. A third was found on 10 March, $7 \mathrm{~cm}$ below the surface in $2^{\circ} \mathrm{C}$ water under silky dogwood roots at the edge of the stream $2.5 \mathrm{~m}$ from its nest. The three hatchlings increased in mass by 12.9 to $19.5 \%$ from autumn release to spring capture, but we cannot partition mass gain between possible autumn feeding and potential winter water uptake.

\section{Discussion}

Although the transmitters were small, they still were up to $\approx 10 \%$ of the body mass of the hatchlings, and potentially could snag on vegetation during locomotion. While we cannot discount effects on behavior, since the hatchlings within a given group behaved similarly, we do not think that transmitter attachment had a major effect on behavior relative to that of an unfettered hatchling.

On Long Island, the four hatchlings that were recovered from their hibernacula in April all overwintered in spring seeps away from standing water, in contrast to the behavior of the New Hampshire hatchlings, which all moved to shallow water and remained there to overwinter. The four Long Island hatchlings also initially moved to open water from their release in the nest cavity (two from each nest), but they then followed different paths, sometimes including both aquatic and terrestrial movements, before eventually settling into the spring seeps for overwintering, as did the fifth, although we could not find it in April. In the sense that Long Island hibernacula were not under standing water, the hibernacula were terrestrial and differed from those expected by assuming that hatchlings move to aquatic lentic or lotic habitats and overwinter there, as was the case with the New Hampshire hatchlings. However, the Long Island hatchlings were surrounded by a constantly saturated medium that appeared to have an underground flow, so desiccation was not a threat. We do not know the oxygen content of the interstitial water, but assume that it was appreciable or the turtles would have died if they had remained submerged throughout the winter. Reese et al. (2004) found that Snapping Turtle hatchlings will die in 30 days if submerged in anoxic water at $3^{\circ} \mathrm{C}$, compared to survival of adults for at least 125 days under similar conditions (Reese at al. 2002). The limited survival of anoxic hatchlings is attributable to their reduced whole-body buffering capacity, and therefore reduced tolerance of the metabolic acidosis that accompanies the accumulation of lactic acid during anaerobiosis. The reduced buffering capacity is due to the reduced relative amount of bone, especially in the shell, of the hatchlings compared to adults, and is a general characteristic of hatchling turtles (Reese et al. 2004). This inability to tolerate anoxia would preclude the turtles from hibernating for extended periods in anoxic conditions, such as mud under standing water. Thus the seep water that surrounded the hatchlings must have had a significant amount of dissolved oxygen, perhaps maintained by a constant percolation of oxygenated spring water that exceeded the biochemical oxygen demand of the detritus at the low wintertime temperatures. Alternatively, it is possible that the hatchlings may have occasionally air-breathed, since the soil surface of the seeps did not freeze during the winter. Airbreathing would require that the animals move to the surface to breathe (on the assumption that the water saturation prevents any underground air pockets from forming); since turtles are not completely immobilized by cold, air-breathing cannot be ruled out. Why the hatchlings moved out of open water to hibernate in the seeps, or how they oriented toward them, is uncertain.

Thus the overwintering habitats of hatchling Snapping Turtles are varied, ranging from the expected shallow-water retreats typical of the New Hampshire hatchlings, to the use of wet but not aquatic sites (e.g., seeps), even though aquatic sites are nearby and easily accessible, as seen with the Long Island hatchlings. The use of seeps as hibernacula for turtles, especially young ones, may be more common than has been appreciated. V. Lamoureaux (personal communication), while studying the use of seeps as hibernacula for Green Frogs (Rana clamitans) in New York (Lamoureux and Madison 1999), found one adult and three 
juvenile $(9.5-11 \mathrm{~cm})$ Snapping Turtles leaving a seep area in late April, where they apparently overwintered, and moving toward a nearby pond. Dunson (1986) radiotracked four snapping turtles in a tidal marsh area in Virginia, and they all moved to seep/spring areas on higher ground, which remained unfrozen throughout the winter, suggesting that the use of seeps as hibernacula may not be limited to immature turtles, although almost all reports of hibernacula of adult Snapping Turtles are of those covered by standing or flowing water (Ultsch 2006).

\section{Acknowledgments}

We thank Sara Zimnavoda for help with radiotracking in Long Island and students of the Aquatic Ecology course at St. Anselm College for similar aid in New Hampshire. This study was supported by a National Science Foundation grant to GRU (IBN 0076592).

\section{Literature Cited}

Baker, P. J., J. P. Costanzo, J. B. Iverson, and R. E. Lee, Jr. 2003. Adaptations to terrestrial overwintering of hatchling northern map turtles, Graptemys geographica. Journal of Comparative Physiology B 173: 643-651.

Baker, P. J., J. P. Costanzo, R. Herlands, R. C. Woods, and R. E. Lee, Jr. 2006. Inoculative freezing promotes winter survival in hatchling diamondback terrapin, Malaclemys terrapin. Canadian Journal of Zoology 84: 116-124.

Cagle, F. R. 1942. Herpetological fauna of Jackson and Union Counties, Illinois. American Midland Naturalist 28: 164200.

Carroll, D. M., and G. R. Ultsch. 2007. Emergence season and survival in the nest of hatchling turtles in southcentral New Hampshire. Northeastern Naturalist 14: 307-310.

Christiansen, J. L., and B. J. Gallaway. 1984. Raccoon removal, nesting success, and hatchling emergence in Iowa turtles with special reference to Kinosternon flavescens. Southwestern Naturalist 29: 343-348.

Costanzo, J. P., J. B. Iverson, M. F. Wright, and R. E. Lee Jr. 1995. Cold hardiness and overwintering strategies of hatchlings in an assemblage of northern turtles. Ecology 76: $1772-1785$.

Draud, M., M. Bossert, and S. Zimnavoda. 2004. Predation on hatchling and juvenile diamondback terrapins (Malaclemys terrapin) by the Norway rat (Rattus norvegicus). Journal of Herpetology 38: 467-470.

Dunson, W. A. 1986. Estuarine populations of the snapping turtle (Chelydra) as a model for the evolution of marine adaptations in reptiles. Copeia 1986: 741-756.

Ernst, C. H. 1966. Overwintering of hatchling Chelydra serpentina in southeastern Pennsylvania. Philadelphia Herpetological Society Bulletin 14: 8-9.

Ernst, C. H. 1976. Ecology of the spotted turtle, Clemmys guttata (Reptilia, Testudines, Testudinidae), in southwestern Pennsylvania. Journal of Herpetology 10: 25-33.
Harding, J. H. 1991. A twenty year wood turtle study in Michigan: implications for conservation. Pages 31-35 in First International Symposium of Turtles and Tortoises: Conservation and Captive Husbandry.

Lamoureux, V. S., and D. M. Madison. 1999. Overwintering habits of radio-implanted green frogs, Rana clamitans. Journal of Herpetology 33: 430-435.

Lindeman, P. V. 1991. Survivorship of overwintering hatchling painted turtles, Chrysemys picta, in northern Idaho. Canadian Field-Naturalist 105: 263-266.

Mitchell, J. C. 1988. Population ecology and life histories of the freshwater turtles Chrysemys picta and Sternotherus odoratus in an urban lake. Herpetological Monographs 2: 40-61.

Nagle, R. D., C. L. Lutz, and A. L. Pyle. 2004. Overwintering in the nest by hatchling map turtles (Graptemys geographica). Canadian Journal of Zoology 82: 1211-1218.

Obbard, M. E., and R. J. Brooks. 1981. Fate of overwintered clutches of the common snapping turtle (Chelydra serpentina) in Algonquin Park, Ontario. Canadian FieldNaturalist 95: 350-352.

Pappas, M. J., B. J. Brecke, and J. D. Congdon. 2000. The Blanding's turtles (Emydoidea blandingii) of Weaver Dunes, Minnesota. Chelonian Conservation and Biology 3: 557-568.

Parren, S. G., and M. A. Rice. 2004. Terrestrial overwintering of hatchling turtles in Vermont nests. Northeastern Naturalist 11: 229-233.

Reese, S. A., D. C. Jackson, and G. R. Ultsch. 2002. The physiology of overwintering in a turtle that occupies multiple habitats, the common snapping turtle (Chelydra serpentina). Physiological and Biochemical Zoology 75 : 432-438.

Reese, S. A., G. R. Ultsch, and D. C. Jackson. 2004. Lactate accumulation, glycogen depletion, and shell composition of hatchling turtles during simulated hibernation. Journal of Experimental Biology 207: 2889-2895.

Standing, K. L., T. B. Herman, D. D. Hurlburt, and I. P. Morrison. 1997. Postemergence behaviour of neonates in a northern peripheral population of Blanding's turtle, Emydoidea blandingii, in Nova Scotia. Canadian Journal of Zoology 75: 1387-1395.

Standing, K. L., T. B. Herman, and I. P. Morrison. 1999. Nesting ecology of Blanding's turtle (Emydoidea blandingii) in Nova Scotia, the northeastern limit of the species' range. Canadian Journal of Zoology 77: 1609-1614.

Tuttle, S. E., and D. M. Carroll. 2005. Movements and behavior of hatchling wood turtles (Glyptemys insculpta). Northeastern Naturalist 12: 331-248.

Ultsch, G. R. 2006. The ecology of overwintering among turtles: Where turtles overwinter and its consequences. Biological Reviews 81: 339-367.

Zwiefel, R. G. 1989. Long-term ecological studies on a population of painted turtles, Chrysemys picta, on Long Island, New York. American Museum Novitates 2952: 1-55.

Received 27 October 2006 Accepted 29 January 2008 